\author{
パルス色素レーザーの励起波長依存性 \\ 前田三男, 高尾 隆之, 興 雄司, 五十嵐 香*, 草間 秀晃** \\ 九州大学システム情報科学研究科電子デバイス工学専攻 (テ812-81 福岡市東区箱崎6-10-1) \\ *千葉工業大学化学工学科 ( 275 千葉県習志野市津田沼2-17-1) \\ **(財) 産業創造研究所 ( 2277 千葉県柏市高田1201)
}

\title{
Effect of Excitation Wavelengths in Pulsed Dye Lasers
}

\author{
Mitsuo MAEDA, Takayuki TAKAO, Yuji OKI, Kaoru IGARASHI*, and Hideaki KUSAMA** \\ Department of Electrical Devices, Graduate School of Information Science and Electrical Engineering, Kyushu University, \\ 6-10-1 Hakozaki, Higashi-ku Fukuoka 812-81 \\ *Department of Industrial and Chemistry, Chiba Institute of Technology, 2-17-1 Tsudanuma, Narashino-shi Chiba 275 \\ **Institute of Research and Innvation, 1201 Takara, Kashiwa-shi Chiba 277
}

(Received September 20, 1996)

\begin{abstract}
In order to develop a high-efficiency pulsed dye laser, laser efficiencies of various dyes were measured at three different pumping wavelengths of the $\mathrm{Cu}$ vapor laser $(511 \mathrm{~nm}$ and $578 \mathrm{~nm}$ ) and the frequency-doubled Nd:YAG laser $(532 \mathrm{~nm})$ in the same condition. A simulation model for Rhodamine $6 \mathrm{G}(\mathrm{R}-6 \mathrm{G})$ dye laser was also developed to analyze the effect of excitation wavelengths. Some Rhodamine dyes show higher efficiency than those of R-6G in simultaneous two-wavelength pumping by a $\mathrm{Cu}$ vapor laser. A dye mixture of Cresyl Violet 670 and Rhodamine 640 was as efficient as R-6G in the $653 \sim 660 \mathrm{~nm}$ region.
\end{abstract}

Key Words: Dye laser, Cu vapor laser, Nd:YAG laser, Laser efficiency, Dye mixture

1.はじめに

銅蒸気レーザー励起色素レーザーが用いられる同位元 素の分離プラントにおいては, その高出力化・高効率化が プラントの経済性を左右する一つのカギを握ってい る1,2). 我々はその観点から前報3ににおいて, Nd:YAGレー ザーの第2高調波 (SHG)を励起源として,30種類のレーザー 色素の同一条件での発振効率の比較を行なった。また同 時に, ローダミン6G色素レーザーをモデルにしたレート方 程式の数值解析を行ない, 色素レーザー発振効率を決める 要因について考察した。 その結果得られた主な結論は次 の通りであった。

1) 波長532nmのNd:YAGレーザーSHGを励起源として各種 色素のレーザー発振効率を測定したところ, 標準にした ローダミン6Gに比ベピロメテン567(発振波長556nm) は 8.8\%高い効率を示した。 また二三のローダミン系色素 (ローダミン 575, ローダミン 640, キトンレッド620)にお いても,ローダミン $6 \mathrm{G}$ とほぼ同等の効率が得られた。

2) 開発したシミュレーションコードを用いて, ローダミン 6G色素レーザーの励起波長依存性を考察した結果, 最適 な励起波長は色素の吸収極大波長より若干長波長にあ り, 実験に使用した532nm励起波長はローダミン6Gに対 しては最適点近くにあることがわかった.

本論文はその研究の続報で, 前回の波長 $532 \mathrm{~nm}$ のみでの
励起実験に対して今回は, 銅蒸気レーザーのグリーンとイ エローの発振線に対応する波長 $511 \mathrm{~nm}$ 及び $578 \mathrm{~nm}$ を加え, 同一条件で3波長の励起に対する発振効率を測定し, 理論解 析結果との比較を行なった。ローダミン $6 \mathrm{G} か ゙ 578 \mathrm{~nm}$ 光を 吸収しないのに対して, 銅蒸気レーザーの2波長を有効に利

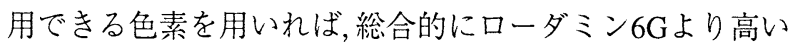
効率が得られることを実験と解析により明らかにした。 また,2種類の色素を混合した場合には, 励起波長に対する 吸収スペクトルの不整合が補正できることを利用し， $532 \mathrm{~nm}$ 励起に対して640nm付近の発振波長域でローダミン 6G(発振波長570nm) とほぼ同程度の効率を実現した。

\section{2. 発振効率の励起波長依存性}

高効率大出力のパルス色素レーザーの励起源としては, 現在銅蒸気レーザー励起色素レーザーが最も実用的であ が, 将来は固体化されたNd:YAGレーザーのSHGも有望で ある．銅蒸気レーザーとNd:YAGレーザーではビームパ ターンやパルス幅が異なるので, 色素の発振効率を厳密に 比較するのは困難である.そこで我々はFig.1に示したよ うな色素レーザーを励起源として, 511, 532, 578nmの3波長 における色素の発振効率を同一に近い条件で測定できる 装置を試作した。

Fig.1の装置の構成は, まずフラッシュランプ励起Qス 
イッチNd:YAGレーザーの第3高調波 (355nm, Spectra Physics GCR-12)で一段目の色素レーザーを励起する。この色 素レーザーは2個の石英プリズムで同調する，色素セル (長さ $10 \mathrm{~mm}$ )を横にして上方向から励起したのは, 次段の 効率測定用色素レーザーへの励起ビームパターンを左右 対称にするためである。

一段目のレーザーに使用した色素は, 波長511nm用には クマリン 500 (濃度 $\left.10^{-3} \mathrm{~mol} / \ell\right), 532 \mathrm{~nm}$ 用にはクマリン $540 \mathrm{~A}$ (濃度 $\left.4 \times 10^{-3} \mathrm{~mol} / \ell\right), 578 \mathrm{~nm}$ 用にはローダミン $6 \mathrm{G}$ (濃度 $2 \times$ $\left.10^{-3} \mathrm{~mol} / \ell\right)$ をいずれもエ夕ノールに溶いて用いた。発振の スペクトル幅はいずれの波長でも $1.8 \mathrm{~nm}$ 以下であった. 出 力は $25 \mathrm{~mJ}$ の THG励起に対していずれも $4 \mathrm{~mJ}$ 程度が得られ た。これは色素の発振効率を十分飽和域で測定できる值 である.パルス幅は5～6ns, 繰り返しは10 Hzである。

効率測定用色素レーザーは前回と同様, アラインメント に左右されにくいシンプルな構成である。一段目の色素 レーザーからの出力ビームは約 $1 \times 10 \mathrm{~mm}$ のスポットサイ ズに整形して, $10 \times 10 \mathrm{~mm}^{2}$ の石英セルに横方向から入射さ せた．共振器はアルミ蒸着鏡と無コートの石英パラレル よりなる $110 \mathrm{~mm}$ 間隔の平行平板型である。セルは端面反
射の影響を受けないよう若干傾けて配置し, 溶液は小型ス ターラーで常時かき混ぜている。

励起光や発振光のパルスエネルギーは相互に校正され た2台の焦電型ジュールメーター (Gentec社, ED-200とED100) とで測定した。発振波長は小型のモノクロメーター （島津UV-160A）を用いて掃引し, 発振スペクトルの中心波 長より求めた.

効率測定は前回高い発振効率を示した約 10 種類の色素 について行ない, Table Iの結果を得た. ここで発振効率と はセルの直前で測った励起光エネルギーに対する発振出 力光エネルギーの比である. 発振効率は濃度によって変 化するので, まず濃度を变化させて効率を測定し, 最大効 率が得られた濃度(これを最適濃度と呼ぶ)において効率と 発振波長を求めた。 その際効率は励起光のエネルギーに よっても変化するが, 前回述べたように入力 $1.5 \sim 2 \mathrm{~mJ}$ 以上 ではほぼ一定值に飽和するので, Table Iに示した值はその 飽和值である，テストした色素の溶媒には特に断わりが ない場合は全てエタノールを使用している。

Table IでNd:YAGレーザーのSHGに対応する波長532nm 励起について, 効率の闌にカッコで示した值は, 前回 $\mathrm{Nd}$ :

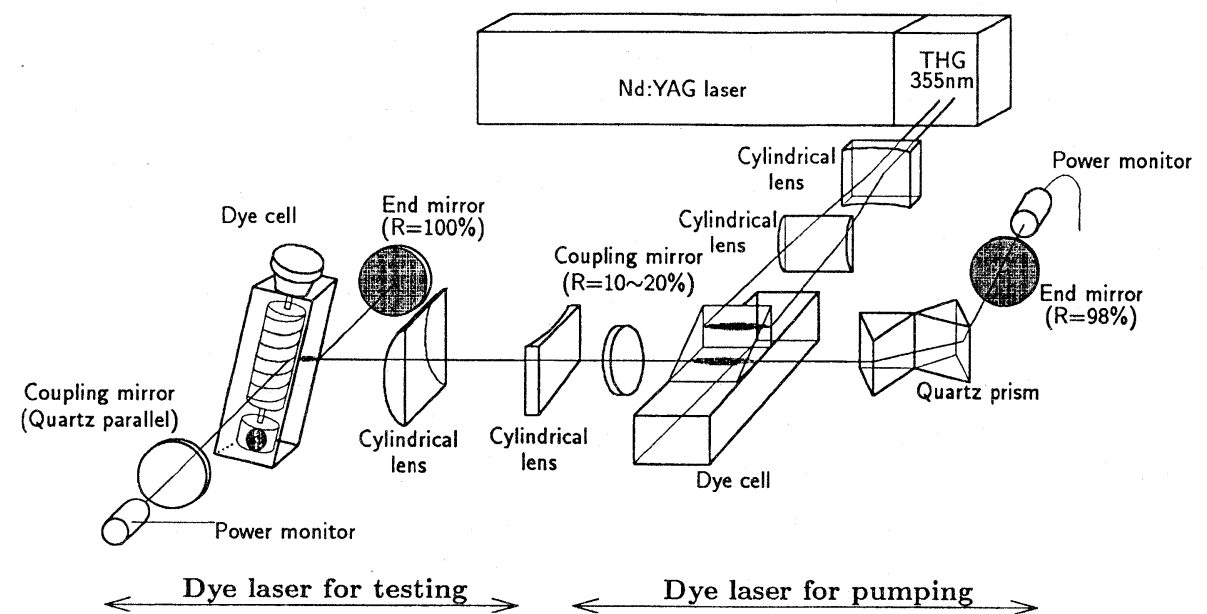

Fig.1 Dye laser for efficiency measurement at three different pumping wavelengths.

Table I Laser efficiencies measured for three different pumping wavelength.

\begin{tabular}{|c|c|c|c|c|c|c|c|}
\hline \multirow[b]{2}{*}{ Dye } & \multicolumn{3}{|c|}{ 511nm pumping } & \multicolumn{2}{|c|}{ 532nm pumping } & \multicolumn{2}{|c|}{ 578nm pumpimg } \\
\hline & $\begin{array}{c}\text { Concentration } \\
(\mathrm{mol} / \ell)\end{array}$ & $\begin{array}{l}\text { Efficiency } \\
(\%)\end{array}$ & $\begin{array}{l}\text { Wavelength } \\
\text { (nm) }\end{array}$ & $\begin{array}{c}\text { Concentration } \\
(\mathrm{mol} / \ell)\end{array}$ & $\begin{array}{c}\text { Efficiency } \\
(\%)\end{array}$ & $\begin{array}{l}\text { Concentration } \\
(\mathrm{mol} / \ell)\end{array}$ & $\begin{array}{c}\text { Efficiency } \\
(\%)\end{array}$ \\
\hline \multicolumn{8}{|l|}{ [Rhodamine dyes] } \\
\hline Rhodamine $6 \mathrm{G}$ & $1.0 \times 10^{-3}$ & 46.1 & 577 & $2.8 \times 10^{-4}$ & $52.1(52.6)$ & - & - \\
\hline Rhodamine 575 & $5.0 \times 10^{-4}$ & 46.8 & 555.5 & $3.5 \times 10^{-4}$ & $47.5(52.6)$ & - & - \\
\hline Rhodamine 610 & $3.3 \times 10^{-4}$ & 35.6 & 593 & $1.2 \times 10^{-3}$ & $44.8(44.0)$ & $8.0 \times 10^{-4}$ & 45.2 \\
\hline Rhodamine 640 & $1.7 \times 10^{-3}$ & 31.5 & 612 & $9.0 \times 10^{-4}$ & $50.5(52.6)$ & $4.0 \times 10^{-4}$ & 51.5 \\
\hline Sulforhodamine 640 & $5.6 \times 10^{-4}$ & 28.4 & 612 & $5.6 \times 10^{-4}$ & $42.2(45.3)$ & $1.2 \times 10^{-4}$ & 43.9 \\
\hline Kiton Red 620 & $6.0 \times 10^{-4}$ & 35.4 & 591 & $4.4 \times 10^{-4}$ & $48.5(50.3)$ & $1.0 \times 10^{-3}$ & 41.5 \\
\hline \multicolumn{8}{|l|}{ [Styryl dyes] } \\
\hline $\mathrm{DCM}^{*}$ & $2.5 \times 10^{-3}$ & 38.0 & 647.5 & $2.0 \times 10^{-3}$ & $46.1(45.9)$ & $6.7 \times 10^{-3}$ & 12.1 \\
\hline \multicolumn{8}{|l|}{ [Pyrromethene dyes] } \\
\hline Pyrromethene 567 & $3.3 \times 10^{-4}$ & 61.2 & 550 & $1.0 \times 10^{-3}$ & $61.6(61.4)$ & - & - \\
\hline Pyrromethene 556* & $3.9 \times 10^{-3}$ & 39.3 & 557 & $4.0 \times 10^{-3}$ & $39.8(45.8)$ & - & - \\
\hline Pyrromethene $556^{* *}$ & $8.0 \times 10^{-3}$ & 48.2 & 548.5 & & & & \\
\hline Pyrromethene $546^{*}$ & $3.0 \times 10^{-3}$ & 45.5 & 535.8 & - & - & - & - \\
\hline
\end{tabular}

( ) shows the previous result by Nd:YAG (SHG) laser pumping. ${ }^{3)}$ Solvent: *DMSO, ** ethylene glycol, and others ethanol. 
YAGレーザーの直接励起により測定した効率である31. 今 回の色素レーザー励起による值とよく一致していること から，測定された効率が信頼性のある值であることを確 認した。日をおいて同一条件で繰り返し測定したデータ から, 測定した効率值は $2 \%$ 程度以内の精度で有意である と考えられる。

波長578nm励起に対してはローダミン $6 \mathrm{G}$ と 575 , 及びピ ロメテン系の3色素は吸収が不完全で発振しなかった。

\section{3. 励起波長依存性についての考察}

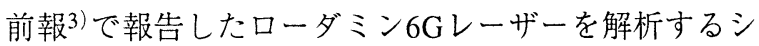
ミュレーションコードを用いてTable Iの結果を考察しよ j.

開発したコードの詳細は前報にあるので,ここでは基 本方程式のみを示す.

$$
\begin{aligned}
& \frac{1}{c} \frac{\partial I^{ \pm}}{\partial t}+\frac{\partial I^{ \pm}}{\partial z}=\left(\sigma_{e} n_{1}-\sigma_{a} n_{0}-\sigma_{s} n_{1}-\sigma_{t} n_{3}\right) I^{ \pm} \\
&+\frac{n_{1}}{\tau} f \\
& \frac{d n_{1}}{d t}= \frac{\sigma_{a p} n_{0}}{h v_{p}} I_{p}-\frac{\sigma_{e} n_{1}-\sigma_{a} n_{0}}{h v} I-k_{S T} n_{1}-\frac{n_{1}}{\tau} \\
& \frac{d n_{3}}{d t}=k_{S T} n_{1}-\frac{n_{3}}{\tau_{T}} \\
& \frac{d I_{p}}{d t}=W-\left(\sigma_{a p} n_{0}+\sigma_{s p} n_{1}\right) c I_{p}
\end{aligned}
$$

ここで $n_{0}, n_{1}, n_{3}$ はそれぞれ基底一重項, 励起一重項, 三重 項準位の色素分子密度, $\sigma_{\mathrm{e}}, \sigma_{\mathrm{a}}, \sigma_{\mathrm{s}}, \sigma_{\mathrm{t}}$ はそれぞれ誘導放出, レーザー光及び励起光に対する基底及び励起一重項準位 からの吸収, 励起三重項吸収の断面積であり, $\sigma_{\mathrm{ap}}, \sigma_{\mathrm{sp}}$ は励 起光に対する基底及び励起一重項準位からの吸収断面積 である， $\tau, \tau_{\mathrm{T}}$ は一重項および三重項の寿命, $k_{\mathrm{ST}}$ は項間交差 率, $c$ は光速, $f$ は蛍光の発振モードへの結合率である. また $I^{+}, I^{-}$は共振器間の左右に進む光の強度であり, $z=0$ と $L$ に おいて $I^{-}(L, t)=R_{0} I+(\mathrm{L}, \mathrm{t}), I+(0, t)=R_{\mathrm{e}} I^{-}(0, t)$ の境界条件 を入れた。ここで $R_{0}$ は出力鏡の反射率, $R_{\mathrm{e}}$ はそれ以外の共 振損失をあたる等価反射率で, これをフィッテングパラ メーターにとり, 実験との比較から $R_{\mathrm{e}}=60 \%$ としている.

セル内の励起光強度 $I_{\mathrm{p}}$ および式 (4)の励起率Wの項はい ずれもセルのある断面積について一様と仮定した。つま りこのシミュレーションは光軸である $z$ 方向の変化のみを 考慮した一次元モデルである。シミュレーションを行な う上で色素分子の分光パラメーターの選び方は重要であ るが,これまでこのコードを用い,ローダミン6Gについて 増幅器の解析 ${ }^{4)}$ と前報での発振器の解析 ${ }^{3)}$ を通じて実験と の比較を種々行ない, パラメーターの最適化に努めてき た。特に色素の濃度特性の解析では, 横方向励起ではセル の奥行き方向にすべて一様とする一次元モデルでは誤差 が生じることが影念されたが, 「励起光はセル内の一定の厚 さでのみ一様に吸収され，その区間で吸収されなかった分 は失われてしまう」という仮定で計算した結果, $2 \times 10^{-5}$ か ら $10^{-2} \mathrm{~mol} / \ell の$ 非常に広い濃度域で実験とよく合う結果が得

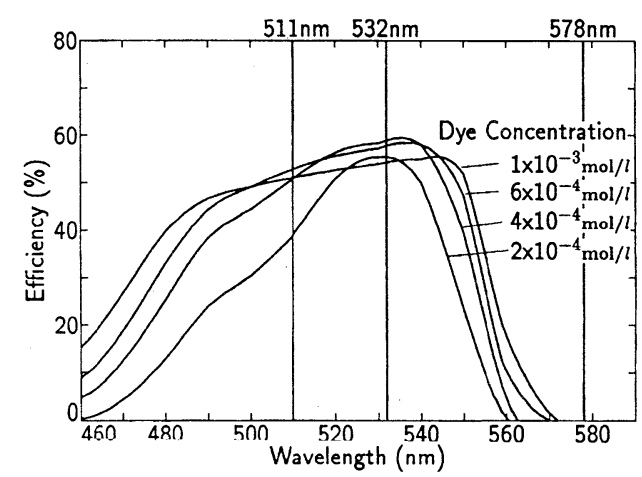

Fig.2 Analytical result of pumping wavelength dependences of efficiency of Rhodamine $6 \mathrm{G}$ laser on dye concentration. $^{3)}$

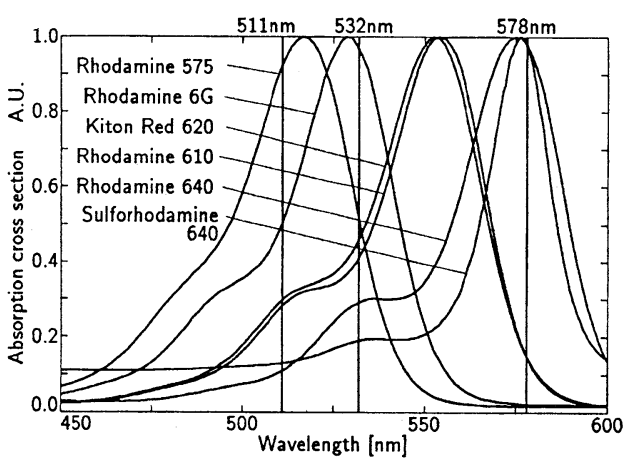

Fig.3 Normalized absorption cross sections of Rhodamine dyes.

られることを前報に示した3)。

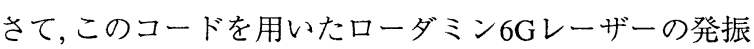
効率の励起波長依存性についてはすでに前報で計算を行 なった。それを用いて今回の実験結果を考察するために， Fig.2にその解析結果を再掲する。色素濃度が低い場合に は励起波長と発振効率の関係はほとんどローダミン $6 \mathrm{G} の$ 吸収スペクトルに近い形をとるが, 濃度を上げると長波 長・短波長に拡がってフラットに近づく. 各励起波長で 濃度の最適化を行なってゆくと,これらの曲線の包絡線が ローダミン $6 \mathrm{G}$ の効率の励起波長依存性を与えることにな る.

このグラフから,効率の励起波長依存性は (1) 励起波長に 対する吸収断面積の大きさと (2) 励起波長と発振波長の差 の2因子によって主に決まっていることがわかる．（2）の因 子は励起光子と発振光子のエネルギー比 $h v / h v_{\mathrm{p}}=v / v_{\mathrm{p}}$ で 与えられるから, 長波長ほどいい. その結果, 最適な励起 波長はその色素の吸収極大波長より若干長波長にくる.

Fig.3にTable Iのローダミン系色素の吸収スペクトルを示 す。ただし吸収断面積は極大波長で規格化している。 Table Iの実験結果によれば, ローダミン6Gの511nm励起に よる発振効率が532nm励起の場合より悪いのは, Fig.2の結 果と定量的にもほぼ一致している。

Table Iにおいて, ローダミン575以外のローダミン系色素 はすべてローダミン6Gより長波長に吸収極大があるた め, $511 \mathrm{~nm}$ 励起の効率は532nm励起の効率と比べるとかな りことなり悪くなっている。 そのかわり, 578nm励起が可 能になり,特にローダミン640は532nm励起以上の効率が得 
られた。ローダミン575のみは吸収極大が短波長にシフト しており, 511nm励起の方が有利にもかかわらず, 実験結果 では532nm励起と同程度の効率しか得られていないのは, 上述の (2)の因子が利いているのであろう。最近,システム の固体化をめざして銅蒸気レーザーをNd:YAGレーザーに 置き換える動きがある，上述の結果によれば，ローダミン 系色素は $511 \mathrm{~nm}$ 励起よりも532nm励起に向いて扔り,この ことは銅蒸気レーザーをNd:YAGレーザーに置き換える際 のポジティブな要因となる.

一方, 今回テストした3種のピロメテン系色素の吸収スペ クトルは前報3 のFig.5に示しててる。吸収極大波長はロー ダミン $6 \mathrm{G}>$ ピロメテン $567>556>546$ の順に短波長へシ フトしている。ローダミン6Gより高い効率を示したピロ メテン567をはじめ,他の二種も532nm励起では吸収極大が 短波長すぎて整合性が悪いので, $511 \mathrm{~nm}$ 励起では大幅な効 率改善が期待された。しかし,ピロメテン567については両 者の効率はほほ同等であった。これは前述の(1)と(2)の因 子がつりあった結果であろう。

他の2つの色素については $511 \mathrm{~nm} の$ 方が高い効率が得ら れたが，ローダミン $6 \mathrm{G}$ を越えるには至らなかった。

Guggenheimerらはアルゴンレーザー (all line) 励起のCW発 振で, ピロメテン556は567より高い効率が得られたと報告 している5)。溶媒をエチレングリコールに変え, 条件を彼

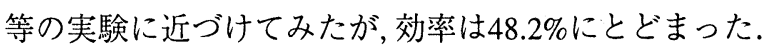

\section{4. 銅蒸気レーザー二波長同時励起}

Table Iの実験では,銅蒸気レーザーの2波長については独 立に効率測定を行なった。そこで, $511 \mathrm{~nm}$ と $578 \mathrm{~nm}$ 光が例 えば7:3の比であった時の総合発振効率 $\eta_{578}$ を,それぞれの 波長での効率 $0.7 \eta_{511}$ と0.3 $\eta_{578}$ の值から単純な重ねあわせに 上り

$$
\eta_{0}=0.7 \eta_{511}+0.3 \eta_{578}
$$

で計算してみると, Table IIを得る。

Tabel IIによると, 578nmの励起光が無駄になるローダミ ン $6 \mathrm{G}$ に比べ,それより吸収スペクトルが長波長にある色素 は2波長同時励起した際に高い総合効率が期待できる。

しかしながら, 総合効率が式(5)によって求められるかど うかに疑問が残る。そこで先のシミュレーションコード を2波長同時励起に修正して,そのことの妥当性を検討し た.

2波長同時励起に対しては, 基本方程式(1)～(4)のうち式 (2)および(4)に次の修正を施した。

Table II Laser efficiencies measured for three different pumping wavelength.

\begin{tabular}{lccc}
\hline \hline Dye & $\eta_{511}$ & $\eta_{578}$ & $\eta_{0}$ \\
\hline Rhodamine 6G & $46.1 \%$ & $0 \%$ & $32.3 \%$ \\
Rhodamine 610 & $35.6 \%$ & $45.2 \%$ & $38.5 \%$ \\
Rhodamine 640 & $31.5 \%$ & $51.5 \%$ & $37.5 \%$ \\
Sulforhodamine 640 & $28.4 \%$ & $43.9 \%$ & $33.1 \%$ \\
Kiton Red & $35.4 \%$ & $41.5 \%$ & $37.4 \%$ \\
\hline \hline
\end{tabular}

第 25 巻第 1 号 パルス色素レーザーの励起波長依存性

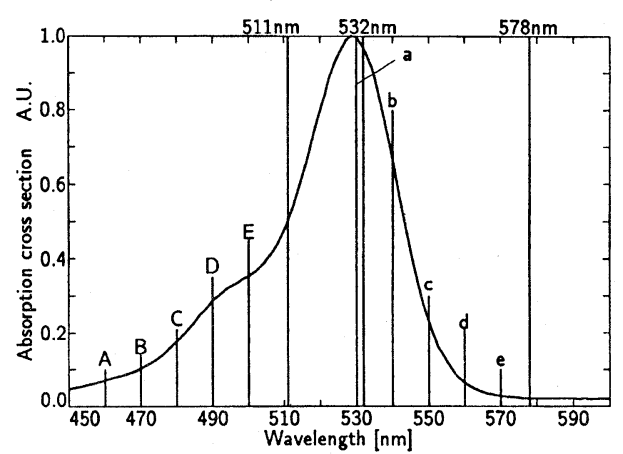

Fig.4 Absorption spectrum of Rhodamine 6G, and combination of two pumping wavelengths used for calculation.

$$
\begin{aligned}
\frac{d n_{1}}{d t}= & \frac{\sigma_{a p 1} n_{0}}{h v_{p 1}} I_{p 1}+\frac{\sigma_{a p 2} n_{0}}{h v_{p 2}} I_{p 2} \\
& -\frac{\sigma_{e} n_{1}-\sigma_{a} n_{0}}{h v} I-k_{s t} n_{1}-\frac{n_{1}}{\tau} \\
\frac{d I_{p 1}}{d t}= & W_{1}-\left(\sigma_{a p 1} n_{0}+\sigma_{s p 1} n_{1}\right) c I_{p 1} \\
\frac{d I_{p 2}}{d t}= & W_{2}-\left(\sigma_{a p 2} n_{0}+\sigma_{s p 2} n_{1}\right) c I_{p 2}
\end{aligned}
$$

ここでサフィックス 1,2 は2つの波長に対応するものとす る.したがって $511 \mathrm{~nm}$ と $578 \mathrm{~nm}$ 光の強度比を $7: 3$ と仮定する と, $W_{1}=0.7 \mathrm{~W}, W_{2}=0.3 W$ となる. 式 $(6) \sim(8)$ は, 励起一重 項の種々の準位に励起された分子は, すべて短い時間内に 励起一重項の基底準位に緩和した後, レーザー遷移が起こ ることから成立する。

数値計算をするにあたってローダミン $6 \mathrm{G}$ は $578 \mathrm{~nm} に$ 吸 収がないため, Fig.4に示すような仮想的なモデルを考え た. Fig.4の吸収スペクトルはローダミン $6 \mathrm{G}$ のものである が,このスペクトルは動かさずに, 励起2波長差を578-511 $\fallingdotseq 70 \mathrm{~nm}$ で一定に保ちつつ, その組合わせをAa(460+ $530 \mathrm{~nm}), \mathrm{Bb}(470+540 \mathrm{~nm}), \mathrm{Cc}(480+550 \mathrm{~nm}), \mathrm{Dd}(490+$ $560 \mathrm{~nm}), \mathrm{Ee}(500+570 \mathrm{~nm})$ と変化させた.ここで短い波長 G波長, 長い波長をY波長と呼ぶことにする。このモデルは 励起を銅蒸気レーザーの2波長に固定して考えると,ローダ ミン $6 \mathrm{G}$ と同等の分光パラメーターを持ち, その吸収 ·蛍光 スペクトルがそれぞれ50nm (Aa), 40nm (Bb), 30nm (Cc),

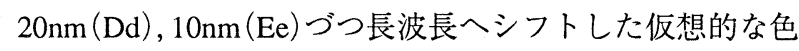
素を考えたのに等しい.

Table IIIに濃度 $10^{-3} \mathrm{~mol} / \ell$ $上$ 述のAa〜Eeについてそれぞ れ1波長独立で求めた効率 $\eta_{\mathrm{G}}, \eta_{\mathrm{Y}}$ から式(5)を用いて計算し た総合効率 $\eta_{0}$ と, 2 波長同時励起のシミュレーションによっ て得られた結果とを示す．両者は非常によく一致してい る。しかし, G波長とY波長では最適濃度が違うのに式(5) では同一濃度で計算しているので, それによる誤差を見積 もるために, さらに色素濃度を $2 \times 10^{-4} \mathrm{~mol} / \ell$ 範囲で動か して同様の計算を行なってみたが, 両者は $\pm 5 \%$ 以内の精度 で一致し,式(5)の妥当性が確かめられた。

Figure 5 は2波長同時励起のコードにより, 総合効率の変 化を計算した結果をまとめたものである，高い色素濃度 ではCcの場合が最も高い効率を示す. 点線はローダミン 
Table III Calculation of overall efficiencies for $\mathrm{Aa} \sim \mathrm{Ee}$ by two methods.

\begin{tabular}{|c|c|c|c|c|c|}
\hline \multicolumn{2}{|c|}{ Pump wavelength } & \multicolumn{4}{|c|}{ Efficiency } \\
\hline & & & & & Simulation of simultaneous \\
\hline & $\mathrm{G}+\mathrm{Y}$ & G only & Y only & Calculation by eq. (5) & $\mathrm{G}+\mathrm{Y}$ pumping \\
\hline $\mathrm{A} \mathrm{a}$ & $460+530 \mathrm{~nm}$ & $15.3 \%$ & $53.9 \%$ & $26.9 \%$ & $26.8 \%$ \\
\hline $\mathrm{B} \mathrm{b}$ & $470+540$ & 26.8 & 54.9 & 35.2 & 35.3 \\
\hline $\mathrm{Cc}$ & $480+550$ & 39.7 & 51.8 & 43.3 & 43.3 \\
\hline $\mathrm{Dd}$ & $490+560$ & 46.6 & 20.1 & 38.7 & 38.7 \\
\hline $\mathrm{Ee}$ & $500+570$ & 49.0 & 1.6 & 34.8 & 34.2 \\
\hline
\end{tabular}

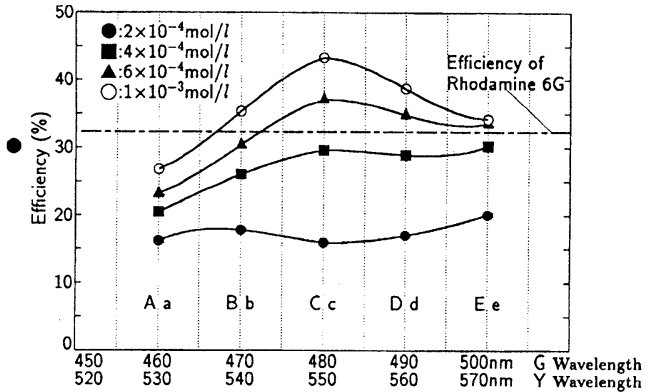

Fig.5 Calculation of overall efficiency for various combinations of $\mathrm{G}$ and $\mathrm{Y}$ wavelengths.

6Gを単独で2波長励起した場合の総合効率である。これは ローダミン $6 \mathrm{G}$ より吸収極大波長が約30nm長波長にある色 素に相当するが, Fig.3を見るとキトンレッド620やローダ ミン610がそれに近い．Fig.3によるとローダミン系色素は いずれもスペクトルの形は一定に近いが, 吸収スペクトル の幅がもう少し広い色素の方が, 当然ながら 2 波長同時励起 の場合は有利になる。

Figure 5で低濃度でCcよりもむしろEeやBbの方が効率が 高い場合があるのは, 2波長同時励起よりも, 単独波長励起 の効率がそれを上まわったことによる。

\section{5. 色素混合の効果}

異なるスペクトルを持った2種類のレーザー色素を混合 する実験はこれまでにも数多くの報告されている6-8).混 合によって期待される効果としては次の3つが考えられ る.

1) 発振波長に対して励起波長が短波長にあり過ぎる場合, 吸収の中継ぎをして励起効率を高める。

2) 2 つ色素の発光スペクトルを組合わせて, 同調域を拡 げる.

3) 2 つ色素の吸収スペクトルを組合わせて, 2 波長 (一般

的には多波長) 同時励起の効率を高める.

同位体分離用レーザーの観点からは1）と3）とが興味深い が, 本節では1)の効果を用いて「ローダミン $6 \mathrm{G} よ り$ 長波長 で, それと同等の効率のレーザー発振できないかりという課 題に取り組んだ。組み合わせる2つの色素のうち短波長側 をドナー, 長波長側をアクセプターと呼ぶことにする．励 起光は主にドナー色素によって吸収された後, 励起エネル ギーがアクセプターに伝搬され，レーザー光はアクセプ 夕一色素が放出する. 励起エネルギー伝搬は放出・再吸 収の放射過程や双極子一双極子相互作用による無放射過 程などによると考えられている99.

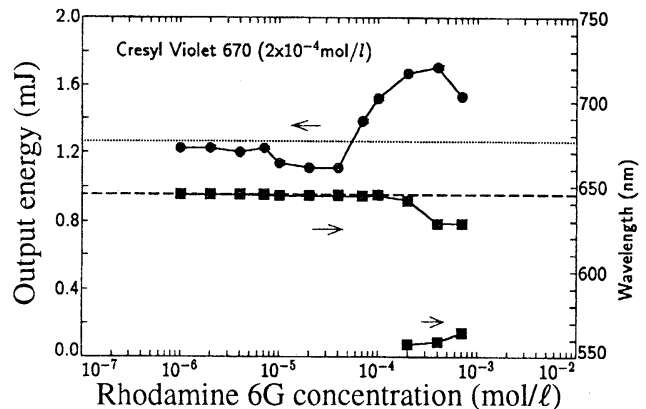

Fig.6 Output energy and laser wavelengths for various mixing ratios of Rhodamine $6 \mathrm{G}$ and Cresyl violet 670 . (Pumping energy is $3.88 \mathrm{~mJ}$ at $532 \mathrm{~nm}$ )

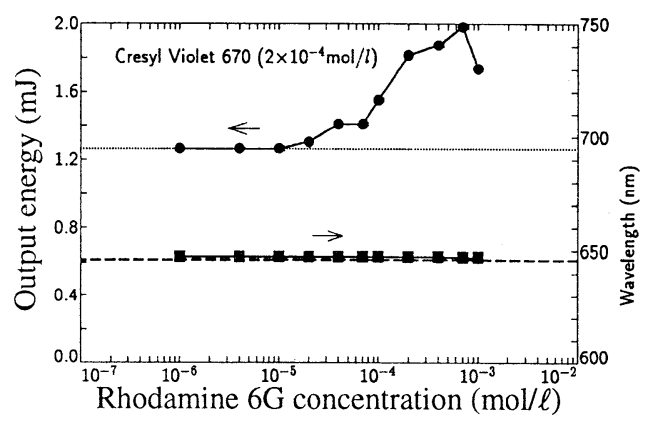

Fig.7 Output energy and laser wavelengths for various mixing ratios of Rhodamine 640 and Cresyl violet 670 . (Pumping energy is $3.88 \mathrm{~mJ}$ at $532 \mathrm{~nm}$ )

同位体分離においてローダミン $6 \mathrm{G} よ り$ 長い波長の光が 必要な場合, Table Iに示したように, 波長600～620nmぐら いまではローダミン 640やキトンレッド620でカバーでき るが, 640nm台になると効率の良いローダミン系色素が見 当たらない. $532 \mathrm{~nm}$ 励起による前回の実験では, DCM (DMSO溶媒で波長650nm, 効率45.9\%), クレジルバイオ レット670(波長646nmで32.6\%), LD700(波長704nmで $35.1 \%)$ などが長波長で効率の良い色素であった ${ }^{3)}$.

今回は励起波長を532nmに固定し, 種々の色素の混合実 験を行なった結果, ローダミン $6 \mathrm{G}+$ クレジルバイオレット 670およびローダミン $640+$ クレジルバイオレット670の組 み合わせに対して1)の効果がみられた。クレジルバイオ レット670の吸収極大波長は600nmにあり, 532nmに対する 吸収は小さいために, 発振効率32.6\%と小さかった. Fig.6 とFig.7は,この2種類の組み合わせに対して混合比を変え た時の出力と発振中心波長である。その際, クレジルバイ オレット670の濃度は単独動作時の最適值 $2 \times 10^{-4} \mathrm{~mol} / \ell$ に固 定し, ドナー色素の濃度を横軸にとっている，点線はアク セプター単独の時の出力でそれを越えた分が混合による 
Table IV Measured laser efficiency and wavelength at optimum mixing ratio.

\begin{tabular}{|c|c|c|c|c|c|}
\hline \multicolumn{2}{|c|}{ Name of dye } & \multirow{2}{*}{$\begin{array}{c}\text { Optimum } \\
\text { concentration } \\
(\mathrm{mol} / \ell)\end{array}$} & \multirow{2}{*}{$\begin{array}{c}\text { Laser } \\
\text { efficiency } \\
(\%)\end{array}$} & \multirow{2}{*}{$\begin{array}{c}\text { Central } \\
\text { wavelength } \\
(\mathrm{nm})\end{array}$} & \multirow{2}{*}{$\begin{array}{l}\text { Tunable } \\
\text { range } \\
(\mathrm{nm})\end{array}$} \\
\hline Donor dye & Acceptor dye & & & & \\
\hline & Rhodamine $6 \mathrm{G}$ & $2 \times 10^{-4}$ & 52.6 & 570 & $550 \sim 590$ \\
\hline & Rhodamine 640 & $4 \times 10^{-4}$ & 52.6 & 615 & $603 \sim 645$ \\
\hline & Cresyl Vilet 670 & $2 \times 10^{-4}$ & 32.6 & 646 & $624 \sim 659$ \\
\hline Rhodamine $6 \mathrm{G}$ & Cresyl Vilet 670 & $4 \times 10^{-4} / 2 \times 10^{-4}$ & 38.6 & 640 & $623 \sim 659$ \\
\hline Rhodamine 640 & Cresyl Vilet 670 & $7 \times 10^{-4} / 2 \times 10^{-4}$ & 50.3 & 645 & $622 \sim 680$ \\
\hline
\end{tabular}

増強効果である.Fig.6で波長が二つに分離しているの は,ドナーとアクセプターが独立に発振しているためであ るが,これは同調を行なうと一本にすることができる。

Table IVに今回の実験で得られた最適な濃度における効 率と発振波長をまとめた。右側の同調域は共振器に斜入 射型回折格子を挿入して測定したもので, それ以外は非同 調時のデータである．このようにローダミン 640 とクレジ ルバイオレット670の混合では波長 $645 \mathrm{~nm}$ で50.3\%という ローダミン6Gに匹敵する効率が実現するとともに, 先の2) で述べた同調域の拡大効果も得られている。

\section{6. むすび}

大出力パルス色素レーザーの励起源として銅蒸気レー ザー(波長511，578nm) とNd:YAGレーザーの第2高調波 $(532 \mathrm{~nm})$ を想定し, その効率改善について種々実験および 理論的検討を行なった結果, 次のような知見が得られた。

1) 与えられた色素の最適励起波長は, その波長での吸収が大 きいことと励起と発振波長の差が小さいことの2因子で 主に決まり,吸収極大波長より若干長波長になる。

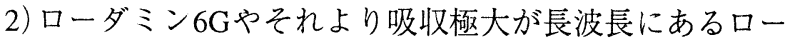
ダミン系色素は532nm励起の方が511nm励起より効率が 高い.

3）上記の観点から吸収極大がローダミン $6 \mathrm{G} よ り$ 短波長に あるピロメテン系色素は532nmより511nm励起の場合に 効率が改善したが, 532nmでローダミン系より高い効率 を示したピロメテン567の511nm励起ではそれと同程度 (61.2\%)の効率であった.

4) ローダミン 610,640 , キトンレッド 620 , スルフォローダ ミン 640 な゙ローダミン $6 \mathrm{G} よ り$ 吸収極大が長波長にある 色素は, $511 \mathrm{~nm}$ と $578 \mathrm{~nm}$ の2波長同時励起に対してローダ ミン6Gより高い総合効率を示した。

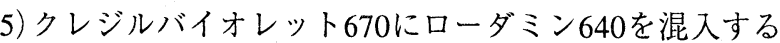
と, 励起波長532nmでは635～660nmの広い波長域にわ たってローダミン $6 \mathrm{G}$ と同等の高い発振効率が実現でき た。

これらの結果は, 今後の同位元素の分離プラントの高効 率化に寄与する重要な知見を与えるものと思われる.

\section{参考文献}

1）レーザー研究「レーザーウラン濃縮特集号」14（1986）397.

2）森岡 昇, 浜田博義, 新井 昇, 佐藤 康彦, 金井 英次, 藤田尚徳： 応用物理 58 (1989) 249.

3）前田三男, 内海 通弘, 高尾隆之, 興雄司, 五十嵐香, 島本 幸次 郎：レーザー研究 23 (1995) 752.

4）前田三男, 内海通弘：レーザー研究 18 (1990) 474.

5) S. G. Guggenheimer, J. H. Boyer, K. Thangaraj, M. Shah, M-L. Soong, and T. G. Pavlopoulos: Appl. Opt. 32 (1993) 3942.

6) C. E. Moeller, C. M. Ver, and A. H. Adelman: Appl. Phys. Lett. 18 (1971) 278.

7) K. Nagashima and T. Asakura: Opt. Comm. 19 (1976) 7.

8) P. Burlamacchi and D. Cutter: Opt. Comm. 22 (1977) 283.

9）長島 健次：電子通信学会論文誌 J64（198）645. 